\title{
Boston University claims scientific successes built on earmarked funds
}

Boston. As November's mid-term elections draw close, the US Congress and its activities have become subject to an unprecedented barrage of public criticism. But the beleagured institution has found itself a friend at Boston University.

In choosing sites for major new scientific facilities, Congress is "the only appropriate body to decide how federal tax dollars should be spent," says John Silber, the university's president. The alternative -- peer review by a panel of scientists - "has conflict of interest built into it almost all the time", he says.

Silber is a fiery iconoclast who stood as Democratic candidate for governor of Massachusetts in 1990. His views are not universally shared; M. R. C. Greenwood, a senior official in the Office of Science and Technology Policy, warned a recent congressional hearing that such views "have the potential of destroying the process" that underpins science in the United States.

But looking across the Charles River from Silber's offices, the appeal of earmarking to this middle-ranking but politically well-connected school is all too obvious. On the opposite bank sits the Massachusetts Institute of Technology (MIT), and half a mile up the road is Harvard University, both well-endowed icons of academic excellence, and both well placed to succeed in any process based on peer review.

In recent testimony to Congress, Silber branded these élite schools "an informal cartel," and compared them with the oil producers' organization OPEC. Membership of the élite, he argued, has been built on first-rate facilities such as MIT's Lincoln Laboratory - funds for which were earmarked by Congress in 1952 .

"Earmarking is the way all of the major research universities got their start," says Silber. Now it's Boston University's turn: since 1985 , the school has attracted three awards of earmarked funds for the construction of research facilities, worth a total of $\$ 56.5$ million.

The first, for a science and engineering centre, has made possible the rapid expansion of the university's engineering school. The second, for a physics and biology building, has helped raise the physics department from a position of relative obscurity to one of acknowledged strength. The third and largest is for $\$ 29$ million to help build a major photonics research centre that could make Boston University the leader in a critical new field of applied science.

In each case, the earmarked funds have enabled the university to attract a larger amount of loans to build the facility. The grant for the photonics centre, for example, includes $\$ 16$ million towards total construction costs of almost $\$ 80$ million. "The federal government is going to get research facilities that cost four or five times what they've put in", Silber says.

Don Fraser, a former engineer at MIT and senior official at the Department of Defense (DoD), who was appointed last year to head the new photonics centre, says that it will emphasize the applications of photonics research. These, he says, go far beyond fibre optic telecommunications to embrace a range of exciting possibilities in medicine, environmental control and consumer electronics.

\section{IMAGE UNAVAILABLE FOR COPYRIGHT REASONS}

\section{Silber (right) praises direct \\ funding of his university's new science and engineering centre (above)}

The process by which the centre won funds from the Department of Defense was complex. After extensive lobbying by Boston University - much of it, Silber says, at the offices of Senator Edward Kennedy (Democrat, Massachusetts) - the \$29 million was included in the defence budget bill passed in 1991.

The Bush administration later sought (unsuccessfully) to rescind funding for the centre among 23 defence earmarks, worth $\$ 170$ million. Reviewing the photonics project in 1992, a DoD review panel rejected it: according to Representative Martin Hoke (Republican, Ohio), the panel's unpublished report branded the proposal as "superficial and not unique".

But at the beginning of 1993 the new DoD team, led by Les Aspin, decided to take a softer line on earmarks. DoD then helped all 23 projects to re-submit proposals, which the panel reviewed and accepted.

"I'm not going to sit here defending that process - it's a superb process," says Silber. "If someone comes up and asks what's two plus two and gets five, and comes back six months later and says 'I made a mistake, two plus two is four', then it is not to be criticized, it is to be complimented."
Silber also defends his use of a Washington-based lobbyist, Gerald Cassidy, who receives $\$ 400,000$ a year from the university. Cassidy's role, he says, is to find out where in the government money might be available, and to arrange meetings for Silber and his staff with the right people. Silber says that the actual selling of the projects is down to himself and his academic staff.

Past earmarking at Boston is now bearing fruit. The amount of peer-reviewed research attracted by the College of Engineering, for example, has grown from $\$ 1.4$ million in 1985 to $\$ 9.2$ million this year.

An even greater expansion has occurred in the physics department, although Silber's recent claim to Congress that it "is now ranked in the top six in the nation for the quality and influence of its research" oversells the progress made under Larry Sulak, who took charge of the department in 1985. Silber's claim is based on an assessment by the Institute of Scientific Information (ISI) in Philadelphia. This ranked Boston University seventh in the number of citations per published paper across all the physical sciences (not just physics) in the period 1987-90(see Nature 349,6; 1991). The main physics earmark was granted by Congress in 1988 .

"If we didn't have this building, we couldn't have done anything," says Sulak of the $\$ 42$ million physics and biology centre, which the \$8-million earmark helped to build. According to more recent ISI figures for the period 1981-93, Boston's physics department had the seventeenth highest citation rate among large physics departments in the US. The number of papers grew rapidly through the period, while their citation rate remained stable.

But the advantages of such a centre are plain for all to see. They include a machine shop, an electronics design and construction facility, and a computer centre, each superbly equipped. There is no money in the main federal science and technology budget for such university-based facilities, and has not been for twenty five years.

In a ringing endorsement of Kennedy, who is standing for re-election, in the Boston Globe on 11 October, Silber vigorously attacked his Republican opponent, Mitt Romney, and praised the veteran senator's clout in Washington, listing expensive federal projects he had brought back home. Oddly, the $\$ 56.5$ million Kennedy has brought to Boston University was absent from the list. "Romney calls this pork," Silber wrote. "I call it the return from Washington of our taxes."

Colin Macilwain 